\title{
Changes of Fatty Acid Profiles and Content of Sterols, Tocopherols and Carotenoids in Pork by Antioxidant Type Phytonutrients
}

\author{
Dessislava Vlahova-Vangelova ${ }^{1}(\mathbb{D})$, Dessislav Balev ${ }^{1(\mathbb{D})}$, Stefan Dragoev ${ }^{1,2, *(\mathbb{D})}$ \\ 1 Department of Meat and Fish Technology, University of Food Technologies, 26 Maritsa Blvd., 4020 Plovdiv, Bulgaria \\ 2 Assembly of Academicians and Corresponding Members, Bulgarian Academy of Sciences, 1 Fifteenth of November Str., \\ 1040 Sofia, Bulgaria \\ * Correspondence: logos2000lt@gmail.com;
}

Scopus Author ID 15727424300

Received: 6.08.2020; Revised: 9.09.2020; Accepted: 12.09.2020; Published: 16.09.2020

\begin{abstract}
The objectives of this study were to determine the effect of 3.5 and $7.5 \mathrm{mg} 96 \%$ Larix sibirica dihydroquercetin $/ \mathrm{kg} / \mathrm{d}$ (samples D1 and D2), or 0.255 and $0.545 \mathrm{~g}$ dry distilled Rosa damascena petals (DDRP) $/ \mathrm{kg} / \mathrm{d}$ (samples R1 and R2) used as supplements to pigs diet until the last $45 \mathrm{~d}$ prior to harvest on fatty acid composition and contents of sterols, tocopherols and carotenoids in Longissimus lumborum et thoracis and Semimembranosus muscles, backfat and leaf fat stored $24 \mathrm{~h}$ at $0-4^{\circ} \mathrm{C}$. The dihydroquercetin or DDRP supplementation increases the amount of unsaturated fatty acids with 1.2 $4.3 \%$ of two muscles and backfat. The addition of DDRP $/ \mathrm{kg} / \mathrm{d}$ to the feed of pigs causes a reduction in the sterols in $\mathrm{m}$. Semimembranosus and backfat, while in leaf fat, no affect. In contrast, the pronounced increase of sterols in $\mathrm{m}$. Longissimus lumborum et thoracis were found when dihydroquercetin or DDRP were added. The supplementation of antioxidant type phytonutrients leads to significant ( $\mathrm{p}<$ 0.05) increase of tocopherols in both muscles and in samples R2 of backfat. The carotenoids decreasing was observed in backfat, $\mathrm{m}$. Longissimus lumborum et thoracis and $\mathrm{m}$. Semimembranosus excluding samples D2 at m. Semimembranosus and samples R1, R2, and D2 leaf fat.
\end{abstract}

Keywords: pigs; pork; taxifolin; Larix sibirica; Rosa damascena; dry distilled rose petals; fatty acid composition; sterols; tocopherols; carotenoids.

(C) 2020 by the authors. This article is an open-access article distributed under the terms and conditions of the Creative Commons Attribution (CC BY) license (https://creativecommons.org/licenses/by/4.0/).

\section{Introduction}

For most consumers, red meat has a negative image because it is widely believed that it contains a lot of fat and is a major source of saturated fatty acid in diet [1]. It is discussed as responsible for modern lifestyle diseases in developed countries. It is, therefore, appropriate to look for mechanisms to lower levels of saturated fatty acids and cholesterol and to make the meat a functional food hence more attractive and healthier. One of the main approaches to healthy eating is the reduction of certain ingredients from food, perceived as components with a negative effect. It is possible to change the negative image of meat by eliminating or severely lowering the fat content and some supplements [2,3]. The literature was discussed several approaches to creating new functional meat products [4]. Some strategies alter the carcass composition associated with a change in proteins, vitamins content, and fatty acid composition has been insufficiently studied. In recent years different researchers [1, 2, 5] have been discussed carcass meat production with a modified chemical composition. The application of 
various natural antioxidants for inhibition of lipid-protein oxidation deterioration in meat and meat products has been also proposed [6].

Dihydroquercetin, also known as taxifolin, is a powerful natural bioflavonoid with antioxidant action, a capillary protective activity, and the absence of mutagenic activity. It has a wide range of positive effects on the metabolic reactions and dynamics of various pathological processes that have been identified in a number of studies [7-13]. In a concentration of about $0.0001-0.00001 \%$ it shows strong antiradical activity and can decrease blood cholesterol and increase the pigs' weight gain [14].

One interesting by-product of the production of rose oil and rose water is the extract of dry distilled rose (Rosa damascena Mill.) petals (DDRP). There is evidence that it contains a wide range of components with synergistic effect and strong antioxidant properties because it is rich in flavonoids and has been used for color stabilization of fruit juices [15]. According to preliminary data, after obtaining $1 \mathrm{~kg}$ of rose oil, a by-product is obtained about $50 \mathrm{~kg}$ of rose petals waste. With an average annual yield of $1500 \mathrm{~kg}$ of rose oil in Bulgaria, approximately $75000 \mathrm{~kg}$ of rose petals can be expected. It is now discarded without being used.

On the one hand, this can lead to environmental pollution. Another possibility is to load the business with additional costs for its use. If the suitable application of Rosa damascena Mill. extract in livestock and the food industry is found; this can lead to significant economic, social, hygienic, and ecological effects. There are reports that experiments have been made to change the composition of chicken minced meat after enrichment of the poultry feed with dry pressed distilled rose petals and dihydroquercetin [16].

In recent years, there has been an interest in applying natural antioxidant phytonutrients as a means for improving the pork nutritional value lead to a higher content of unsaturated fatty acids (UFA) with possible human health benefice [17]. No available data exist on the effects of dihydroquercetin or DDRP dietary supplementation on pork fatty acid composition, sterols, tocopherols, and carotenoids content.

Sterols (in particular in the meat they are presented mainly as cholesterol) are important regulators of membrane fluidity and permeability. They are responsible for membraneassociated metabolic processes in eukaryotic cell membranes [18]. The oxidized cholesterols (so-called oxycholesterols) can efficiently be absorbed into the blood and connected with the low-density lipoprotein (LDL) [19]. Diets rich in phenolic compounds decrease oxidation and reduced levels of cholesterol content [17]. As typical atherogens many oxycholesterols have an ability to modulate the cholesterol metabolism by HMG-CoA reductase enzyme [20]. Fresh pork practically contains 0 or trace amounts of cholesterol oxides[20].

The natural diterpenes - tocopherols have vitamin E activity. They are primary lipidsoluble antioxidants in biological systems [21]. The polyphenolic compounds with the high free radical-scavenging ability [22] can be used in animal' feed with the aim to help maintain the UFA and tocopherol content in meat.

Carotenoids are widespread isoprenoid secondary metabolites. They are shown to provide diverse health benefits. Their relevance from a nutritional standpoint is unarguable. Thay can be converted into vitamin A. The diet is a key factor affecting the carotenoid content in biological tissues. The study of carotenoids in animals is important in the context of the increasing interest of consumers in the authentication of animal diets [23]. The ability of carotenoids to inhibit oxymyoglobin oxidation and to reduce ferryl myoglobin and per-ferryl myoglobin can be used as a natural compound for improving the color stability of meat. The $\beta$-carotene has a relationship with atherosclerosis and cardiovascular disease and shows a 
particularly inhibitory effect on LDL oxidation. These roles of carotenoids in health make their quantitative determination in meat important [24]. The $\beta$-carotene has a relationship with atherosclerosis and cardiovascular disease and shows a particularly inhibitory effect on LDL oxidation. These roles of carotenoids in health make their quantitative determination in meat important [24].

Therefore, the objectives of this study were to determine the effect of 3.5 , and $7.5 \mathrm{mg}$ dihydroquercetin (96\% isolate from Larix sibirica Ledeb)/kg/d (samples D1 and D2 respectively), or 0.255 and $0.545 \mathrm{~g}$ dry distilled rose (Rosa damascena Mill.) petals $/ \mathrm{kg} / \mathrm{d}$ (samples R1 and R2 respectively) used as supplements to pigs commercial diet until the last 45 $\mathrm{d}$ prior to harvest on fatty acid composition and contents of sterols, tocopherols and carotenoids in Longissimus lumborum et thoracis and Semimembranosus muscles, backfat and leaf fat stored $24 \mathrm{~h}$ at $0-4^{\circ} \mathrm{C}$.

\section{Materials and Methods}

\subsection{Animal housing and diets treatments.}

The experiment was conducted at the State Enterprise Experimental Farm at Agricultural Institute, Shumen, Bulgaria. Danube White pigs were created by crossing Bulgarian White, Large White, Landras, and Pietren, then crossing with Hampshire sires. The resulting offspring were randomly allocated to five treatments (one control and four experimental), each containing 24 animals per group. Controls (C) pigs received a typical commercial diet. The diet ingredients and composition were published previously [25]. The four experimental samples were fed the same commercial diets containing either $3.5 \mathrm{mg}$ dihydroquercetin/kg/d (D1); $7.5 \mathrm{mg}$ dihydroquercetin/kg/d (D2); $0.255 \mathrm{~g} \mathrm{DDRP} / \mathrm{kg} / \mathrm{d}$ (R1); or $0.545 \mathrm{~g} \mathrm{DDRP} / \mathrm{kg} / \mathrm{d}$ (R2). Animals care began at weaning when pigs were 35 days of age. Pigs were equalized by origin, age, weight, and sex and allocated to five groups - one by the treatments, 24 pigs each group, accommodated together, all in one stable. The feeding and health status of the pigs were regularly monitored throughout the period after weaning. When reaching an average live weight of $33 \mathrm{~kg}$ at 97 days after birth, all pigs were weighed again and moved to another stable equipped with individual boxes with feeders and drinkers. The pigs were equalized again by sex, age, and live weight. The experiment was divided into two subperiods, with the growing period starting at about $33 \mathrm{~kg}$ live weight and ended at about $72 \mathrm{~kg}$ live weight. No treatment was applied at this period. The fattening period starting at $72 \mathrm{~kg}$ lived weight at 155 days after birth and ended at about $110 \mathrm{~kg}$ live weight. The enrichment of the diets with both concentrations of dihydroquercetin and DDRP started at this time and lasted 45 days, until 200 days after the birth of pigs, when they were slaughtered. The pig diets were weighed daily before being placed in individual feeders twice a day. Residual feed was monitored daily and was weighed and subtracted from the daily amount of feed consumed. , The daily dose of the supplements, were calculated according to the previous day weight gain, weighed and mixed with feed mixture, and given to the animals with the morning feeding. Water was provided at libitum and was assured by nipple drinkers. Animals were weighed every two weeks. Average weight gain and feed consumption were calculated. Temperature, relative humidity and velocity of the air, and harmful gases, such as carbon dioxide, ammonia, hydrogen sulfide, and methane were monitored daily.

At the end of the feeding period, pigs were identified and transported to a processing plant (Unitemp Ltd., Voyvodinovo village, Maritza municipality, Plovdiv district). After $18 \mathrm{~h}$ 
of lariage, pigs were showered and harvested in accordance with normal industry processing procedures and in accordance with requirements of Article 9(3) of the Ordinance No 15 of May 8, 2009. Carcasses were split and chilled to $0-4^{\circ} \mathrm{C}$.

\subsection{Supplements.}

Powdered dihydroquercetin was provided by the company Flavitlife Bio JSCo (Sofia, Bulgaria). The supplement represents powder concentrate (2R,3R-dihydroquercetin) contained $96 \%$ dihydroquercetin, $3 \%$ dihydrokaempferol, and $<1 \%$ naringenin.

Distilled rose petals were supplied by rose oil distillery Damascena, village of Skobelevo, municipality of Pavel Banya, Stara Zagora district, part of Bulattars Production Company Ltd (Sofia, Bulgaria). After distillation, the rose petals were collected, pressed, dried, and ground to particle size $<0.4 \mathrm{~mm}$. The DDRP were rich in polyphenolic compounds: gallic acid glycosides $1.43 \pm 0.04 \mathrm{mg} / \mathrm{g}$, quercetin-3-O-galactoside $0.96 \pm 0.18 \mathrm{mg} / \mathrm{g}$, quercetin 3-Oglucoside $0.79 \pm 0.10 \mathrm{mg} / \mathrm{g}$, sum of quercetin glycosides $1.98 \pm 0.05 \mathrm{mg} / \mathrm{g}$; sum of kaempferol glycosides $1.97 \pm 0.05 \mathrm{mg} / \mathrm{g}$; kaempferol $0.22 \pm 0.03 \mathrm{mg} / \mathrm{g}$ [26]. According to the literature data $[14,27,28]$ and our previous experience $[25,29]$ the doses of phytonutrient supplements were formulated based on concentrations and antioxidant activity of their polyphenolic compounds [30] and for dihydroquercetin were offered 3.5 and $7.5 \mathrm{mg} / \mathrm{kg} / \mathrm{d}$, and for DDRP 0.242 and $0.545 \mathrm{mg} / \mathrm{kg} / \mathrm{d}$.

\subsection{Sample preparation.}

After $24 \mathrm{hr}$ chilling $\left(0-4^{\circ} \mathrm{C}\right)$, muscles Longissimus thoracis et lumborum and Semimembranosus, backfat or leaf fat was removed from each carcass and sampled immediately. Chilled muscles or fat was ground through $3 \mathrm{~mm}$ grinder plates, mixed and homogenized, thus preparing an average laboratory sample. From this average laboratory sample, 9 replicates $(n=9)$ were taken in the analyzes of the studied fatty acid profiles, sterols, tocopherols, and carotenoids.

\subsection{Lipid extraction.}

Total lipids were extracted from the chopped and minced muscle and fat tissues by Bligh \& Dyer method and after evaporation of the eluent immediately were used for next lipid analyses. The lipids of meat were isolated by hydrolyzing the sample with hydrochloric acid, and the fat released is extracted by petroleum ether, recovered, and calculated as a percentage by weight of the original sample [31].

\subsection{Determination of fatty acid profiles.}

The fatty acid composition of triacylglycerols was determined by gas chromatography (GC) after transmethylation of the respective sample with $2 \% \mathrm{H}_{2} \mathrm{SO}_{4}$ in absolute $\mathrm{CH}_{3} \mathrm{OH}$ at $50^{\circ} \mathrm{C}$ [32]. Fatty acid methyl esters (FAME) were purified by thin-layer chromatography (TLC) on $20 \times 20 \mathrm{~cm}$ plates covered with $0.2 \mathrm{~mm}$ silica gel $60 \mathrm{G}$ (Merck) layer with a mobile phase nhexane:diethyl ether (97:3, v/v). GC was performed on an HP 5890 series II (Hewlett Packard GesmbH, Vienna, Austria) gas chromatograph equipped with a $30 \mathrm{~m}$ x $0.25 \mathrm{~mm}$ (I.D.) x 0.2 $\mu \mathrm{m}$ (film thickness) capillary column SupelcoTM SP-2380 and a flame ionization detector. The column temperature was programmed from $70^{\circ} \mathrm{C}(1 \mathrm{~min})$, at $6^{\circ} \mathrm{C} / \mathrm{min}$ to $190^{\circ} \mathrm{C}(0 \mathrm{~min})$, at $10^{\circ} \mathrm{C} / \mathrm{min}$ to $250^{\circ} \mathrm{C}(0 \mathrm{~min})$; injector and detector temperatures were kept at $250^{\circ} \mathrm{C}$. Hydrogen 
was the carrier gas at a flow rate $0.8 \mathrm{~mL} / \mathrm{min}$; the split was 1:50. Identification of fatty acids was performed by comparison of retention times with those of a standard mixture of fatty acids subjected to GC under identical experimental conditions [33].

\subsection{Determination of sterols.}

Unsaponifiables were determined after saponification of the glycerides oil and extraction with hexane using the standard method [34]. Quantification of sterols was carried out spectrophotometrically (at $597 \mathrm{~nm}$ ), after isolation of sterols from other unsaponifiable matter by TLC [35]. Sterol composition was determined on HP 5890 gas chromatograph equipped with $25 \mathrm{~m} \times 0.25 \mathrm{~mm} \mathrm{DB}-5$ capillary column and flame ionization detector. The temperature gradient from $90^{\circ} \mathrm{C}$ (hold $3 \mathrm{~min}$ ) up to $290^{\circ} \mathrm{C}$ at a rate of change $15^{\circ} \mathrm{C} / \mathrm{min}$ and then up to $310^{\circ} \mathrm{C}$ a rate of $4^{\circ} \mathrm{C} / \mathrm{min}$ (hold $10 \mathrm{~min}$ ); detector temperature $-320^{\circ} \mathrm{C}$; injector temperature $-300^{\circ} \mathrm{C}$ and carrier gas was hydrogen. Identification was confirmed by comparison of retention times with those of a standard mixture of sterols [36].

\subsection{Determination of tocopherols.}

The tocopherols were determined by ISO 9936:2016 method [37]. The determination was carried out directly in the lipids by HPLC analysis on a Merck-Hitachi (Merck, Darmstadt, Germany) instrument equipped with $250 \mathrm{~mm}$ x $4 \mathrm{~mm}$ Nucleosil Si 50-5 column and fluorescent detector Merck-Hitachi F 1000. The operating conditions were a mobile phase of $n$-hexane: dioxane, $96: 4(\mathrm{v} / \mathrm{v})$, and flow rate $1 \mathrm{~mL} / \mathrm{min}$, excitation $295 \mathrm{~nm}$, emission $330 \mathrm{~nm} .20 \mu \mathrm{L} \mathrm{1 \%}$ solution of crude oil in n-hexane was injected. Tocopherols were identified by comparing the retention times with those of authentic individual ones. The tocopherol content was calculated on the base of tocopherol peak areas in the sample vs. tocopherol peak area of the standard tocopherol solution.

\subsection{Determination of carotenoids.}

The carotenoids were determined by the spectrophotometric method [38]. $1 \mathrm{~g}$ of the fat was dissolved in $20 \mathrm{ml}$ of hexane and then the total carotenoids measured spectrophotometrically at $452 \mathrm{~nm}$ using double beam UV-Vis scanning spectrophotometer M550 (Spectronic Camspec Ltd, Garforth, Leeds LS25 1DX, United Kingdom).

\subsection{Statistical analysis.}

Data were expressed as means \pm SEM $(n=9$. Repetitions were performed on a preprepared average laboratory sample including muscle or adipose tissues from 24 pigs for each of the 5 groups of examined animals) and were processed using the variation statistics methods with software package Minitab 16 Statistical software [39]. The one-way ANOVA was used on the data, followed by Student's t-test for multiple comparisons. The statistically significant differences were identified at $\mathrm{p}<0.05$. 


\section{Results and Discussion}

3.1. Effect of the antioxidant type phytonutrient supplementation on the fatty acid composition of the pigs' muscle and fatty tissues.

The use of dihydroquercetin and DDRP supplementation in pigs' diet has little effect on the fatty acid composition of $\mathrm{m}$. Semimembranosus, $1 \mathrm{~d}$ post mortem $\left(0-4^{\circ} \mathrm{C}\right)$. The total amount of saturated fatty acids (SFA) varied between 41.8 - 44.6\% (Table 1).

A comparison with the other four samples shows that the SFA of samples R1 was significantly $(\mathrm{p}<0.05)$ lower with $1-2 \%$, mainly due to low levels of stearic acid C18:0. At the same time, levels of unsaturated fatty acids (UFA) in samples R1 increased by a similar percentage, mainly associated with a small but statistically significant $(\mathrm{p}<0.05)$ increase in levels of palmitoleic acid C16:1, oleic acid C18:1, and linolenic acid C18:3 (Table 1).

Table 1. Fatty acid composition of $\mathrm{m}$. Semimembranosus $1 \mathrm{~d}$ post mortem storage at $0-4^{\circ} \mathrm{C}$.

Fatty acids, g/100 g total lipids

Lauric acid $\mathrm{C} 12: 0$

Myristic acid C 14:0

Pentadecylic acid C 15:0

Palmitic acid C 16:0

Palmitoleic acid C 16:1

Margaric acid C 17:0

Heptadecenoic acid C17:1

Stearic acid C 18:0

Oleic acid C 18:1

Linoleic acid C 18:2

Linolenic acid C 18:3

Arachidic acid C 20:0

Eicosadienoic acid C 20:2

Saturated fatty acids (SFA)

Unsaturated fatty acids (UFA)

Monounsaturated fatty acids

(MUFA)

Polyunsaturated fatty acids (PUFA

Total lipids, g/100 g

a, b, c, d, e Means in the same row with differ using one-way ANOVA. $(\mathrm{n}=9)$

Comparisons of SFA and UFA in m. Longissimus lumborum et thoracis between controls C and samples D2, R1, and R2 were found they are small, and divisions were in the range of $1.2 \%$ (Table 2). Contrary only in samples D1 was found an increase of UFA with approx. $4.3 \%$. This increase ( $\mathrm{p}<0.05$ ) was most pronounced at levels of oleic acid C18:1 and palmitoleic acid C16:1 registered in samples D1 (Table 2).

The impact of antioxidant type phytonutrients on fatty acid profiles of adipose tissue was different from this determined in the lipids of two studied muscles. The use of feed with dietary supplements of dihydroquercetin or DDRP differently affected the fatty acid composition of the subcutaneous fat, so-called backfat (Table 3). Data of the backfat samples show that, in comparison with the controls $\mathrm{C}$, in samples, D1 was found to have about $2 \%$ higher content of UFA, mainly due to the increased content of oleic acid C 18:1.

In contrast, the addition of dihydroquercetin or DDRP to the forage of pigs affects the fatty acid profiles of leaf fat by reducing with $1.6-3.6 \%$ UFA in the samples R1, D2, and D1, and increasing their content in the samples D2 with 5.2\% (Table 4). Nearest to the fatty acid composition of the leaf fat of controls $\mathrm{C}$ were those determined in samples D1 - leaf fat in pigs fed with feed enriched with the addition of $3.5 \mathrm{mg}$ dihydroquercetin $/ \mathrm{kg} / \mathrm{d}$. 
The primary findings of this study is that the fatty acid composition of different muscles and type of adipose tissue affected in different ways. As a result, in the fatty acid profiles of the four samples (D1, D2, R1, and R2) were found divergent trends compared to that of the controls C. Practically, this might be due to the complex of reasons. Although both muscles (m. Longissimus lumborum et thoracis and $\mathrm{m}$. Semimembranosus) examined are classified as glycolytic type; they are distinguished by myofibrillar compositions, metabolic characteristics, which is caused by differences in their gene expression profiles [40].

Table 2. Fatty acid composition of $\mathrm{m}$. Longissimus lumborum et thoracis $1 \mathrm{~d}$ post mortem storage at $0-4^{\circ} \mathrm{C}$.

Fatty acids, g/100 g total lipids

\begin{tabular}{|c|c|c|c|c|c|}
\hline Fatty acids, g/100 g total lipids & Controls (C) & Samples (D1) & Samples (D2) & Samples (R1) & Samples (R2) \\
\hline Lauric acid C12:0 & - & $0.1^{\mathrm{a}} \pm 0.01$ & $0.1^{\mathrm{a}} \pm 0.01$ & - & $0.1^{\mathrm{a}} \pm 0.01$ \\
\hline Myristic acid C 14:0 & $1.7^{\mathrm{a}} \pm 0.04$ & $1.7^{\mathrm{a}} \pm 0.04$ & $1.8^{\mathrm{b}} \pm 0.03$ & $1.8^{\mathrm{b}} \pm 0.01$ & $1.8^{\mathrm{b}} \pm 0.02$ \\
\hline Pentadecylic acid C 15:0 & $0.1^{\mathrm{a}} \pm 0.01$ & - & - & - & $0.1^{\mathrm{a}} \pm 0.01$ \\
\hline Palmitic acid C 16:0 & $30.7^{\mathrm{a}} \pm 1.20$ & $29.7^{\mathrm{a}} \pm 1.00$ & $31.3^{\mathrm{a}} \pm 1.00$ & $31.8^{\mathrm{a}} \pm 0.80$ & $31.5^{\mathrm{a}} \pm 0.9$ \\
\hline Palmitoleic acid C 16:1 & $2.0^{\mathrm{a}} \pm 0.10$ & $2.9^{\mathrm{b}, \mathrm{c}} \pm 0.05$ & $2.8^{\mathrm{b}, \mathrm{c}} \pm 0.10$ & $2.7^{b} \pm 0.05$ & $3.0^{\mathrm{c}} \pm 0.10$ \\
\hline Margaric acid C 17:0 & $0.2^{\mathrm{a}} \pm 0.01$ & $0.2^{\mathrm{a}} \pm 0.01$ & $0.2^{\mathrm{a}} \pm 0.01$ & $0.2^{\mathrm{a}} \pm 0.01$ & $0.2^{\mathrm{a}} \pm 0.01$ \\
\hline Heptadecenoic acid C 17:1 & $0.3^{\mathrm{a}} \pm 0.05$ & $0.2^{\mathrm{a}} \pm 0.05$ & $0.2^{\mathrm{a}} \pm 0.05$ & $0.2^{\mathrm{a}} \pm 0.05$ & $0.2^{\mathrm{a}} \pm 0.05$ \\
\hline Stearic acid C 18:0 & $16.2^{\mathrm{c}} \pm 0.70$ & $13.0^{\mathrm{a}} \pm 0.80$ & $14.6^{\mathrm{a}, \mathrm{b}} \pm 0.80$ & $14.6^{\mathrm{b}} \pm 0.50$ & $14^{\mathrm{a}, \mathrm{b}} \pm 0.40$ \\
\hline Oleic acid C 18:1 & $45.1^{\mathrm{a}} \pm 1.60$ & $49.5^{\mathrm{b}} \pm 1.40$ & $47.0^{\mathrm{a}} \pm 1.00$ & $45.3^{\mathrm{a}} \pm 1.00$ & $46.3^{\mathrm{a}} \pm 1.20$ \\
\hline Linoleic acid C 18:2 & $2.7^{\mathrm{d}} \pm 0.05$ & $1.5^{\mathrm{b}} \pm 0.15$ & $1.1^{\mathrm{a}} \pm 0.15$ & $2.1^{\mathrm{c}} \pm 0.20$ & $1.7^{\mathrm{b}} \pm 0.20$ \\
\hline Linolenic acid C 18:3 & $0.6^{\mathrm{a}} \pm 0.05$ & $0.9^{\mathrm{c}} \pm 0.05$ & $0.6^{\mathrm{a}} \pm 0.05$ & $0.8^{\mathrm{b}} \pm 0.10$ & $0.7^{\mathrm{a}, \mathrm{b}} \pm 0.10$ \\
\hline Arachidic acid C 20:0 & $0.3^{\mathrm{b}} \pm 0.01$ & $0.2^{\mathrm{a}} \pm 0.01$ & $0.2^{\mathrm{a}} \pm 0.02$ & $0.3^{\mathrm{b}} \pm 0.01$ & $0.3^{\mathrm{b}} \pm 0.01$ \\
\hline Eicosadienoic acid C 20:2 & $0.1^{\mathrm{a}} \pm 0.01$ & $0.1^{\mathrm{a}} \pm 0.01$ & $0.1^{\mathrm{a}} \pm 0.01$ & $0.2^{\mathrm{b}} \pm 0.01$ & $0.1^{\mathrm{a}} \pm 0.01$ \\
\hline Saturated fatty acids (SFA) & $49.2^{\mathrm{c}} \pm 0.29$ & $44.9^{\mathrm{a}} \pm 0.30$ & $48.2^{\mathrm{b}} \pm 0.27$ & $48.7^{b} \pm 0.25$ & $48.0^{b} \pm 0.31$ \\
\hline Unsaturated fatty acids(UFA) & $50.8^{\mathrm{a}} \pm 0.23$ & $55.1^{\mathrm{c}} \pm 0.27$ & $51.8^{\mathrm{b}} \pm 0.20$ & $51.3^{\mathrm{b}} \pm 0.24$ & $52.0^{\mathrm{b}} \pm 0.44$ \\
\hline Monounsaturated fatty acids (MUFA) & $47.4^{a} \pm 0.25$ & $52.6^{d} \pm 0.29$ & $50.0^{c} \pm 0.27$ & $48.2^{b} \pm 0.21$ & $49.5^{c} \pm 0.23$ \\
\hline Polyunsaturated fatty acids (PUFA) & $3.4^{c} \pm 0.14$ & $2.5^{b} \pm 0.11$ & $1.8^{a} \pm 0.10$ & $3.1^{c} \pm 0.13$ & $2.5^{b} \pm 0.12$ \\
\hline Total lipids, g/100 g & $5.43 \pm 0.76$ & $5.27 \pm 0.67$ & $5.76 \pm 0.43$ & $5.68 \pm 0.55$ & $5.12 \pm 0.24$ \\
\hline
\end{tabular}

Table 3. Fatty acid composition of backfat $1 \mathrm{~d}$ post mortem storage at $0-4{ }^{\circ} \mathrm{C}$.

\begin{tabular}{l|l|l|l|l|} 
Fatty acids, g/100 g total lipids & Controls (C) & Samples (D1) & Samples (D2) & Samples (R1)
\end{tabular}

\begin{tabular}{|c|c|c|c|c|c|}
\hline Fatty acids, $\mathrm{g} / 100 \mathrm{~g}$ total lipids & Controls (C) & Samples (D1) & Samples (D2) & Samples (R1) & Samples (R2) \\
\hline Lauric acid C12:0 & $0.1^{\mathrm{a}} \pm 0.01$ & $0.1^{\mathrm{a}} \pm 0.01$ & $0.1^{\mathrm{a}} \pm 0.01$ & - & $0.1^{\mathrm{a}} \pm 0.01$ \\
\hline Myristic acid C 14:0 & $1.8^{\mathrm{a}, \mathrm{b}} \pm 0.20$ & $1.7^{\mathrm{a}} \pm 0.15$ & $2.3^{\mathrm{c}} \pm 0.20$ & $2.1^{\mathrm{b}, \mathrm{c}} \pm 0.20$ & $2.0^{\mathrm{b}, \mathrm{c}} \pm 0.15$ \\
\hline Pentadecylic acid C 15:0 & $0.1^{\mathrm{a}} \pm 0.01$ & $0.1^{\mathrm{a}} \pm 0.01$ & $0.1^{\mathrm{a}} \pm 0.01$ & $0.1^{\mathrm{a}} \pm 0.01$ & $0.1^{\mathrm{a}} \pm 0.01$ \\
\hline Palmitic acid C 16:0 & $32.5^{\mathrm{b}} \pm 1.00$ & $30.3^{\mathrm{a}} \pm 0.70$ & $38.9^{\mathrm{d}} \pm 1.00$ & $32.9^{\mathrm{b}, \mathrm{c}} \pm 1.00$ & $34.8^{\mathrm{c}} \pm 1.00$ \\
\hline Palmitoleic acid C 16:1 & $1.2^{\mathrm{a}} \pm 0.20$ & $1.0^{\mathrm{a}} \pm 0.10$ & $1.9^{\mathrm{b}} \pm 0.20$ & $1.2^{\mathrm{a}} \pm 0.15$ & $1.2^{\mathrm{a}} \pm 0.15$ \\
\hline Margaric acid C 17:0 & $0.4^{\mathrm{a}} \pm 0.05$ & $0.5^{\mathrm{a}, \mathrm{b}} \pm 0.07$ & $0.5^{\mathrm{a}, \mathrm{b}} \pm 0.08$ & $0.5^{\mathrm{a}, \mathrm{b}} \pm 0.07$ & $0.6^{\mathrm{b}} \pm 0.07$ \\
\hline Heptadecenoic acid C17:1 & $0.4^{\mathrm{b}} \pm 0.02$ & $0.5^{c} \pm 0.02$ & $0.4^{\mathrm{b}} \pm 0.02$ & $0.3^{\mathrm{a}} \pm 0.03$ & $0.3^{\mathrm{a}} \pm 0.02$ \\
\hline Stearic acid C 18:0 & $18.7^{\mathrm{b}} \pm 0.70$ & $18.6^{\mathrm{b}} \pm 1.50$ & $10.6^{\mathrm{a}} \pm 1.10$ & $17.9^{\mathrm{b}} \pm 1.50$ & $18.5^{\mathrm{b}} \pm 1.40$ \\
\hline Oleic acid C 18:1 & $38.8^{\mathrm{a}} \pm 1.00$ & $42.0^{\mathrm{b}} \pm 1.60$ & $39.5^{\mathrm{a}, \mathrm{b}} \pm 1.00$ & $40.7^{\mathrm{a}, \mathrm{b}} \pm 1.20$ & $38.7^{\mathrm{a}} \pm 1.00$ \\
\hline Linoleic acid C 18:2 & $4.6^{\mathrm{c}} \pm 0.10$ & $3.9^{\mathrm{b}} \pm 0.20$ & $4.6^{\mathrm{c}} \pm 0.20$ & $3.2^{\mathrm{a}} \pm 0.20$ & $2.9^{\mathrm{a}} \pm 0.30$ \\
\hline Linolenic acid C 18:3 & $0.9^{\mathrm{d}} \pm 0.05$ & $0.7^{\mathrm{c}} \pm 0.05$ & $0.6^{\mathrm{b}, \mathrm{c}} \pm 0.07$ & $0.5^{\mathrm{b}} \pm 0.10$ & $0.3^{\mathrm{a}} \pm 0.04$ \\
\hline Arachidic acid C 20:0 & $0.2^{\mathrm{a}} \pm 0.01$ & $0.3^{b} \pm 0.05$ & $0.3^{\mathrm{b}} \pm 0.02$ & $0.2^{\mathrm{a}} \pm 0.01$ & $0.2^{\mathrm{a}} \pm 0.01$ \\
\hline Eicosadienoic acid C 20:2 & $0.3^{\mathrm{b}} \pm 0.01$ & $0.3^{\mathrm{b}} \pm 0.01$ & $0.2^{\mathrm{a}} \pm 0.01$ & $0.4^{\mathrm{c}} \pm 0.05$ & $0.3^{\mathrm{b}} \pm 0.01$ \\
\hline Saturated fatty acids (SFA) & $53.8^{c} \pm 0.39$ & $51.6^{\mathrm{a}} \pm 0.34$ & $52.8^{\mathrm{b}} \pm 0.36$ & $53.7^{\mathrm{c}} \pm 0.38$ & $56.3^{\mathrm{d}} \pm 0.40$ \\
\hline Unsaturated fatty acids (UFA) & $46.2^{\mathrm{b}} \pm 0.25$ & $48.4^{\mathrm{d}} \pm 0.28$ & $47.2^{\mathrm{c}} \pm 0.26$ & $46.3^{b} \pm 0.23$ & $43.7^{\mathrm{a}} \pm 0.22$ \\
\hline Monounsaturated fatty acids (MUFA) & $40.4^{a} \pm 0.19$ & $43.5^{c} \pm 0.27$ & $41.8^{b} \pm 0.21$ & $42.2^{b} \pm 0.24$ & $40.2^{a} \pm 0.20$ \\
\hline Polyunsaturated fatty acids (PUFA) & $5.8^{e} \pm 0.10$ & $4.9^{c} \pm 0.10$ & $5.4^{d} \pm 0.17$ & $4.1^{b} \pm 0.09$ & $3.5^{a} \pm 0.08$ \\
\hline Total lipids, g/100 g & $88.69 \pm 0.67$ & $88.97 \pm 0.72$ & $89.00 \pm 0.62$ & $88.98 \pm 0.73$ & $89.01 \pm 0.74$ \\
\hline
\end{tabular}

a, b, c, d, e Means in the same row with different superscript letters differ significantly $(\mathrm{p}<0.05)$. The statistical analysis was conducted in rows using one-way ANOVA. $(\mathrm{n}=9)$

Table 4. Fatty acid composition of leaf fat $1 \mathrm{~d}$ post mortem storage at $0-4^{\circ} \mathrm{C}$.

Fatty acids, g/100 g total lipids

Lauric acid $\mathrm{C} 12: 0$

Myristic acid C 14:0

Pentadecylic acid C 15:0

Palmitic acid C 16:0

Palmitoleic acid C 16:1

Margaric acid C 17:0

Heptadecenoic acid $\mathrm{C} 17: 1$

https://biointerfaceresearch.com/

\begin{tabular}{|c|c|c|c|c|}
\hline Controls (C) & Samples (D1) & Samples (D2) & Samples (R1) & Samples (R2) \\
\hline $0.1^{\mathrm{a}} \pm 0.01$ & $0.1^{\mathrm{a}} \pm 0.01$ & $0.1^{\mathrm{a}} \pm 0.01$ & $0.2^{\mathrm{a}} \pm 0.01$ & $0.1^{\mathrm{a}} \pm 0.01$ \\
\hline $2.2^{\mathrm{a}} \pm 0.20$ & $2.3^{\mathrm{a}} \pm 0.10$ & $2.2^{\mathrm{a}} \pm 0.20$ & $2.3^{\mathrm{a}} \pm 0.20$ & $2.1^{\mathrm{a}} \pm 0.20$ \\
\hline $0.1^{\mathrm{a}} \pm 0.01$ & $0.2^{\mathrm{b}} \pm 0.01$ & $0.1^{\mathrm{a}} \pm 0.01$ & $0.1^{\mathrm{a}} \pm 0.01$ & $0.1^{\mathrm{a}} \pm 0.01$ \\
\hline $33.7^{\mathrm{b}} \pm 1.0$ & $33.5^{\mathrm{a}, \mathrm{b}} \pm 0.70$ & $34.0^{\mathrm{b}} \pm 0.80$ & $34.8^{\mathrm{b}} \pm 0.60$ & $32.1^{\mathrm{a}} \pm 1.00$ \\
\hline $1.3^{\mathrm{a}} \pm 0.30$ & $1.4^{\mathrm{a}} \pm 0.40$ & $1.9^{\mathrm{a}} \pm 0.40$ & $1.3^{\mathrm{a}} \pm 0.40$ & $1.6^{\mathrm{a}} \pm 0.40$ \\
\hline $0.4^{\mathrm{a}} \pm 0.03$ & $0.6^{\mathrm{b}} \pm 0.05$ & $0.4^{\mathrm{a}} \pm 0.05$ & $0.5^{\mathrm{b}} \pm 0.05$ & $0.4^{\mathrm{a}} \pm 0.04$ \\
\hline $0.2^{\mathrm{a}} \pm 0.01$ & $0.5^{\mathrm{c}} \pm 0.03$ & $0.4^{\mathrm{b}, \mathrm{c}} \pm 0.08$ & $0.2^{\mathrm{a}} \pm 0.03$ & $0.3^{\mathrm{b}} \pm 0.04$ \\
\hline
\end{tabular}




\begin{tabular}{|c|c|c|c|c|c|}
\hline Fatty acids, g/100 g total lipids & Controls (C) & Samples (D1) & Samples (D2) & Samples (R1) & Samples (R2) \\
\hline Stearic acid C 18:0 & $17.2^{\mathrm{b}} \pm 0.60$ & $18.7^{\mathrm{c}} \pm 0.50$ & $20.3^{\mathrm{d}} \pm 0.60$ & $19.4^{\mathrm{c}, \mathrm{d}} \pm 0.60$ & $13.8^{\mathrm{a}} \pm 0.60$ \\
\hline Oleic acid C 18:1 & $42.1^{\mathrm{b}} \pm 1.20$ & $37.9^{\mathrm{a}} \pm 1.20$ & $38.1^{\mathrm{a}} \pm 1.10$ & $38.7^{\mathrm{a}} \pm 1.20$ & $46.5^{\mathrm{c}} \pm 1.20$ \\
\hline Linoleic acid C 18:2 & $1.9^{\mathrm{b}, \mathrm{c}} \pm 0.20$ & $4.1^{\mathrm{d}} \pm 0.50$ & $1.5^{\mathrm{a}} \pm 0.10$ & $1.8^{\mathrm{a}, \mathrm{b}} \pm 0.20$ & $2.2^{\mathrm{c}} \pm 0.10$ \\
\hline Linolenic acid C 18:3 & $0.2^{\mathrm{a}} \pm 0.01$ & $0.5^{\mathrm{c}} \pm 0.03$ & $0.5^{\mathrm{c}} \pm 0.03$ & $0.3^{\mathrm{b}} \pm 0.03$ & $0.3^{\mathrm{b}} \pm 0.02$ \\
\hline Arachidic acid C 20:0 & $0.2^{\mathrm{b}} \pm 0.01$ & $0.1^{\mathrm{a}} \pm 0.01$ & $0.2^{\mathrm{b}} \pm 0.01$ & $0.2^{\mathrm{b}} \pm 0.01$ & $0.2^{\mathrm{b}} \pm 0.01$ \\
\hline Eicosadienoic acid C 20:2 & $0.4^{\mathrm{d}} \pm 0.02$ & $0.1^{\mathrm{a}} \pm 0.01$ & $0.3^{\mathrm{c}} \pm 0.02$ & $0.2^{\mathrm{b}} \pm 0.01$ & $0.3^{\mathrm{c}} \pm 0.01$ \\
\hline Saturated fatty acids (SFA) & $53.9^{\mathrm{b}} \pm 0.35$ & $55.5^{\mathrm{c}} \pm 0.33$ & $57.3^{\mathrm{d}} \pm 0.39$ & $57.5^{\mathrm{d}} \pm 0.31$ & $48.8^{\mathrm{a}} \pm 0.30$ \\
\hline Unsaturated fatty acids (UFA) & $46.1^{\mathrm{c}} \pm 0.22$ & $44.5^{\mathrm{b}} \pm 0.20$ & $42.7^{a} \pm 0.27$ & $42.5^{\mathrm{a}} \pm 0.24$ & $51.3^{\mathrm{d}} \pm 0.29$ \\
\hline Monounsaturated fatty acids (MUFA) & $43.6^{b} \pm 0.23$ & $39.8^{a} \pm 0.18$ & $40.4^{a} \pm 0.28$ & $40.2^{a} \pm 0.20$ & $48.5^{c} \pm 0.27$ \\
\hline Polyunsaturated fatty acids (PUFA) & $2.5^{b} \pm 0.10$ & $4.7^{c} \pm 0.16$ & $2.3^{a} \pm 0.10$ & $2.3^{a} \pm 0.11$ & $2.8^{b} \pm 0.22$ \\
\hline Total lipids, g/100 g & $94.18 \pm 0.54$ & $94.16 \pm 0.70$ & $93.98 \pm 0.81$ & $94.05 \pm 0.66$ & $94.11 \pm 0.79$ \\
\hline
\end{tabular}

On the other hand, the intramuscular lipids and especially triglycerides were not strictly related to the metabolic muscle type. The studied glycolytic muscles are low in phospholipids [41], and the fatty acid composition of their triacylglycerols is not affected by muscle fiber type and crossbreeding, but is strongly influenced by the rearing system [42]. The activity of their metabolic and contractile enzymes probably influences the observed changes in the fatty acid composition of both muscles, too [43].

Other factors affected by pork fatty acid composition of studied samples can be dietary fat sources, levels, and feeding intervals [44], breed, sex, and halothane genotype [45], dietary oil supplementation [46], and oxidative stability of edible oils [47].

3.2. Effect of the antioxidant type phytonutrient supplementation on the content of sterols, tocopherols, and carotenoids of the pigs' muscle and fatty tissues.

\subsubsection{Sterols.}

The content of sterols in two studied muscles varied by an amplitude of 0.12-0.32 g/100 g. In comparison, the fluctuations of sterols in both types of adipose tissue ranging from 0.04 to $0.16 \mathrm{~g} / 100 \mathrm{~g}(\mathrm{p}<0.05)$ (Table 5). The addition of $0.255 \mathrm{~g}$ and $0.545 \mathrm{~g} \mathrm{DDRP} / \mathrm{kg} / \mathrm{d}$ to the feed of pigs for fattening causes a reduction in the sterol content in $\mathrm{m}$. Semimembranosus, whereas the dihydroquercetin supplementation, does not affect the levels of muscle sterols, and they are not statistically different $(\mathrm{p}>0.05)$ compared to controls $\mathrm{C}$.

In contrast, the sterol content in $\mathrm{m}$. Longissimus lumborum et thoracis was more than twice as high when both dihydroquercetin and DDRP were added to the feed of pigs for fattening. Compared to controls $\mathrm{C}$, the most significant increase $(\mathrm{p}<0.05)$ in sterols was observed in samples D2.

In backfat, some reduction $(\mathrm{p}<0.05)$ of the sterol content was found in all samples compared to controls $\mathrm{C}$, more clearly expressed in samples R1 and R2, while in leaf fat, no statistically significant $(\mathrm{p}>0.05)$ differences were found in sterol content of controls and experimental samples (Table 5).

\subsubsection{Tocopherols.}

There were no clearly expressed tendencies of increase or decrease in the tocopherol content in both tested muscles and types of adipose tissue, depending on the type and concentration of the phytonutrient supplementation of pig's feed (Table 5). The addition of antioxidant type phytonutrients to the feed of pigs for fattening leads to a significant $(\mathrm{p}<0.05)$ increase in the levels of muscle tocopherols in both studied muscles. An exception to this was 
found only at samples D2 in $\mathrm{m}$. Semimebranosus, in which a significant $(\mathrm{p}<0.05)$ decrease in the content of tocopherols was recorded (Table 5). Compared to controls $\mathrm{C}$, the tocopherol content in $\mathrm{m}$. Semimebranosus was found to be more than 4 times higher in samples D2 but in m. Longissimus lumborum et thoracis was more than 5 times higher in samples R2.

Table 5. Content of sterols, tocopherols, and carotenoids in $\mathrm{m}$. Longissimus lumborum et thoracis, $\mathrm{m}$. Semimembranosus, backfat, and leaf fat $1 \mathrm{~d}$ post mortem, stored at $0-4^{\circ} \mathrm{C}$.

\begin{tabular}{|c|c|c|c|c|c|}
\hline Compounds & Controls (C) & Samples (D1) & Samples (D2) & Samples (R1) & Samples (R2) \\
\hline \multicolumn{6}{|c|}{ m. Semimembranosus } \\
\hline Sterols, g/100 g & $0.32^{\mathrm{b}} \pm 0.07$ & $0.32^{b} \pm 0.07$ & $0.30^{\mathrm{b}} \pm 0.05$ & $0.15^{\mathrm{a}} \pm 0.05$ & $0.17^{\mathrm{a}} \pm 0.05$ \\
\hline Tocopherols, $\mathrm{mg} / \mathrm{kg}$ & $12.00^{\mathrm{b}} \pm 1.50$ & $25.00^{\mathrm{d}} \pm 2.20$ & $54.00^{\mathrm{e}} \pm 3.50$ & $20.00^{\mathrm{c}} \pm 2.50$ & $4.00^{\mathrm{a}} \pm 0.80$ \\
\hline Carotenoids, $\mathrm{mg} / \mathrm{kg}$ & $24.50^{\mathrm{b}} \pm 2.50$ & $6.90^{\mathrm{a}} \pm 1.20$ & $32.40^{\mathrm{c}} \pm 2.10$ & $8.10^{\mathrm{a}} \pm 1.60$ & $23.80^{\mathrm{b}} \pm 2.00$ \\
\hline \multicolumn{6}{|c|}{ m. Longissimus lumborum et thoracis } \\
\hline Sterols, g/100 g & $0.12^{\mathrm{a}} \pm 0.03$ & $0.28^{\mathrm{b}} \pm 0.03$ & $0.32^{\mathrm{c}} \pm 0.03$ & $0.25^{\mathrm{b}} \pm 0.03$ & $0.23^{\mathrm{b}} \pm 0.03$ \\
\hline Tocopherols, $\mathrm{mg} / \mathrm{kg}$ & $5.00^{\mathrm{a}} \pm 0.80$ & $15.00^{\mathrm{b}} \pm 1.50$ & $16.00^{\mathrm{b}} \pm 1.30$ & $15.00^{\mathrm{b}} \pm 1.70$ & $27.00^{\mathrm{c}} \pm 2.20$ \\
\hline Carotenoids, $\mathrm{mg} / \mathrm{kg}$ & $36.20^{\mathrm{d}} \pm 2.80$ & $30.20^{\mathrm{c}} \pm 2.00$ & $22.60^{\mathrm{b}} \pm 1.80$ & $18.90^{\mathrm{a}} \pm 1.40$ & $29.90^{\mathrm{c}} \pm 1.30$ \\
\hline \multicolumn{6}{|c|}{ Backfat } \\
\hline Sterols, g/100 g & $0.16^{\mathrm{c}} \pm 0.03$ & $0.10^{\mathrm{b}} \pm 0.01$ & $0.08^{\mathrm{a}, \mathrm{b}} \pm 0.03$ & $0.04^{\mathrm{a}} \pm 0.02$ & $0.05^{\mathrm{a}} \pm 0.02$ \\
\hline Tocopherols, $\mathrm{mg} / \mathrm{kg}$ & $21.00^{\mathrm{b}} \pm 1.90$ & $13.00^{\mathrm{a}} \pm 2.00$ & $24.00^{\mathrm{b}} \pm 2.20$ & $23.00^{\mathrm{b}} \pm 2.50$ & $38.00^{\mathrm{c}} \pm 3.00$ \\
\hline Carotenoids, $\mathrm{mg} / \mathrm{kg}$ & $29.70^{\mathrm{d}} \pm 1.30$ & $10.60^{\mathrm{b}} \pm 1.00$ & $13.60^{\mathrm{c}} \pm 1.00$ & $15.70^{\mathrm{a}} \pm 1.10$ & $3.70^{\mathrm{a}} \pm 0.80$ \\
\hline \multicolumn{6}{|c|}{ Leaffat } \\
\hline Sterols, g/100 g & $0.06^{\mathrm{a}} \pm 0.01$ & $0.07^{\mathrm{a}} \pm 0.02$ & $0.04^{\mathrm{a}} \pm 0.01$ & $0.04^{\mathrm{a}} \pm 0.01$ & $0.08^{\mathrm{a}} \pm 0.03$ \\
\hline Tocopherols, $\mathrm{mg} / \mathrm{kg}$ & $19.00^{c} \pm 1.70$ & $4.00^{\mathrm{a}} \pm 0.50$ & $23.00^{\mathrm{d}} \pm 2.50$ & $45.00^{\mathrm{e}} \pm 3.00$ & $14.00^{\mathrm{b}} \pm 1.50$ \\
\hline Carotenoids, $\mathrm{mg} / \mathrm{kg}$ & $7.90^{\mathrm{a}} \pm 0.80$ & $8.70^{\mathrm{a}} \pm 0.60$ & $10.60^{\mathrm{b}} \pm 0.80$ & $11.10^{\mathrm{b}} \pm 0.70$ & $11.50^{\mathrm{b}} \pm 0.50$ \\
\hline
\end{tabular}

In the backfat, no significant differences $(p \geq 0.05)$ in the content of tocopherols between samples C, D2, and R1 were found. The content of tocopherols was the highest ( $\mathrm{p}<$ $0.05)$ in samples R2. Only in samples D1, some reduction $(p<0.05)$ of tocopherols was determined compared to controls $\mathrm{C}$.

At least the tocopherols were contained in the samples D1 - only $4.00 \mathrm{mg} / \mathrm{kg}$. In the samples R1, the content of tocopherols was more than twice higher than those of controls $\mathrm{C}$, but in samples, R2 was lower with $5.00 \mathrm{mg} / \mathrm{kg}$ comparing to controls $\mathrm{C}$.

The oxidative stability of the fat component of feed can affect bioactive microconstituents, such as tocopherols in meat [48]. However, our findings of increasing the content of tocopherols in muscle and fat samples at some type of treatment can be useful for health promotion and for the prevention of socially important cardiovascular diseases [49]. Practically, this might be due to the use of natural antioxidant supplements in the feed, which are responsible for inhibition of oxidative processes and especially of cholesterol oxidation [50]. Once in the body of pigs through the feed, dehydroquercetin, quercetin, and campherol glucosides inhibited the aggregation of platelets and superoxide produced by xanthine oxidase [51]. The antioxidative defense of dihydroquercetin and flavonoid glucosides from DDRP may not be directly mediated by the removal of free radicals but probably due to their interaction with the cell membrane [52].

\subsubsection{Carotenoids.}

Comparing to the controls $\mathrm{C}$, the trend of the lower content of carotenoids was observed in samples of backfat, m. Longissimus lumborum et thoracis and m. Semimembranosus. Two exceptions were found for samples D2 and R2 at $\mathrm{m}$. Semimembranosus, the first of which showed a significant $(\mathrm{p}<0.05)$ increase in the content of carotenoids, and the second showed no significant differences $(\mathrm{p} \geq 0.05)$ compared to controls $\mathrm{C}$ (Table 5). 
In leaf fat, the lowest content of carotenoids was found in controls $\mathrm{C}$ and samples D1, with no significant $(\mathrm{p} \geq 0.05)$ differences between them. In rest, three samples $\mathrm{R} 1, \mathrm{R} 2$ and D2, the content of carotenoids were 1.3 times higher $(\mathrm{p}<0.05)$.

\section{Conclusions}

The addition of 3.5 or $7.5 \mathrm{mg} 96 \%$ dihydroquercetin isolate from Larix sibirica Ledeb/kg/d or 0.255 or $0.545 \mathrm{~g}$ dry distilled Rosa damascena petals $/ \mathrm{kg} / \mathrm{d}$ to the feed of pig for fattening until the last $45 \mathrm{~d}$ prior to harvest significantly change the saturation of fatty acid profile and contents of sterols, tocopherols and carotenoids in Longissimus lumborum et thoracis and Semimembranosus muscles, backfat and leaf fat stored $24 \mathrm{~h}$ at $0-4^{\circ} \mathrm{C}$ excluding the content of sterols in leaf fat. Thus identified changes are marked different trends in the two studied muscles and in the two types of adipose tissue. They are differently affected by the amount and type of supplemented feed phytonutrients.

In general, the studied supplements can be used to increase the unsaturated nature of intramuscular fats and those of adipose tissue under the skin and from the internal cavities.

\section{Funding}

This work was funded by the Bulgarian National Science Fund (BNSF), Ministry of Education and Science of Republic of Bulgaria, grant number DN 06/8-17/12/2016. The study of the mechanism of biologically active compounds of plant origin accumulation in the organism of Bulgarian breed agricultural animals and their impact on the meat quality as a natural functional food.

\section{Acknowledgments}

The authors acknowledge to the Flavitlife Bio JSCo (Sofia, Bulgaria), and Bulattars Production Company Ltd (Sofia, Bulgaria) - Damascena rose oil distillery, village of Skobelevo, municipality of Pavel Banya, Stara Zagora district for their support and help.

\section{Conflicts of Interest}

The authors declare no conflict of interest.

\section{References}

1. Godfray, H.C.J.; Aveyard, P.; Garnett, T.; Hall, J.W.; Key, T.J.; Lorimer, J.; Jebb, S.A. Meat consumption, health, and the environment. Sci. 2018, 361, https://doi.org/10.1126/science.aam5324.

2. Jasińska, K.; Kurek, A. The effect of oil plants supplementation in pig diet on quality and nutritive value of pork meat. Anim. Sci. Papers Rep. 2017, 35, 137-146.

3. Nguyen, D.V.; Flakemore, A.R.; Otto, J.; Ives, S.W.; Smith, R.W.; Nichols, P.D.; Malau-Aduli, A.E.O. Nutritional value and sensory characteristics of meat eating quality of Australian prime lambs supplemented with pelleted canola and flaxseed oils: Fatty acid profiles of muscle and adipose tissues. Int. Med. Rev. 2017, 3, 1-21, http://dx.doi.org/10.18103/imr.v3i3.295.

4. Khan, R.S.; Grigor, J.; Winger, R.; Win, A. Functional food product development - opportunities and challenges for food manufacturers. Trends Food Sci. Technol. 2013, 30, 27-37, https://doi.org/10.1016/j.tifs.2012.11.004.

5. Francisco, A.; Dentinho, M.T.; Alves, S.P.; Portugal, P.V.; Fernandes, F.; Sengo, S.; Jerónimo, E.; Oliveira, M.A.; Costa, P.; Sequeira, A.; Bessa, R.J.B.; Santos-Silva, J. Growth performance, carcass and meat quality of lambs supplemented with increasing levels of a tanniferous bush (Cistus ladanifer L.) and vegetable oils. Meat Sci. 2015, 100, 275-282, https://doi.org/10.1016/j.meatsci.2014.10.014. 
6. Falowo, A.B.; Fayemi, P.O.; Muchenje, V. Natural antioxidants against lipid-protein oxidative deterioration in meat and meat products: A review. Food Res. Int. 2014, 64, 171-181, https://doi.org/10.1016/j.foodres.2014.06.022.

7. Bischoff, S.C. Quercetin: potentials in the prevention and therapy of disease. Cur. Opin. Clin. Nutr. Metabolic Care 2008, 11, 733-740, https://doi.org/10.1097/MCO.0b013e32831394b8.

8. Goliomytis, M.; Tsoureki, D.; Simitzis, P.E.; Charismiadou, M.A.; Hager-Theodorides, A.L.; Deligeorgis, S.G. The effects of quercetin dietary supplementation on broiler growth performance, meat quality, and oxidative stability. Poultry Sci. 2014, 93, 1957-1962, https://doi.org/10.3382/ps.2013-03585.

9. Hager-Theodorides, A.L.; Goliomytis, M.; Delis, S.; Deligeorgis, S. Effects of dietary supplementation with quercetin on broiler immunological characteristics. Anim. Feed Sci. Technol. 2014, 198, 224-230, https://doi.org/10.1016/j.anifeedsci.2014.09.021.

10. Sugihara, N.; Arakawa, T.; Ohnishi, M.; Furuno, K. Anti- and pro-oxidative effects of flavonoids on metalinduced lipid hydroperoxide-dependent lipid peroxidation in cultured hepatocytes loaded with $\alpha$-linolenic acid. Free Rad.l Biol. Med. 1999, 27, 1313-1323, https://doi.org/10.1016/S0891-5849(99)00167-7.

11. Plotnikov, M.B.; Aliev, O.I.; Maslov, M.J.; Vasiliev, A.S.; Tjukavkina, N.A. Correction of haemorheological disturbances in myocardial infarction by diquertin and ascorbic acid. Phytoter. Res. 2003, 17, 86-88, https://doi.org/10.1002/ptr.1082.

12. Artem'eva, O.A.; Pereselkova, D.A.; Fomichev, Y.P. Dihydroquercetin, the bioactive substance, to be used against pathogenic microorganisms as an alternative to antibiotics. Agric. Biol. 2015, 50, 513-519, https://doi.org/10.15389/agrobiology.2015.4.513eng.

13. Zeka, K.; Ruparelia, K.; Arroo, R.R.J.; Budriesi, R.; Micucci, M. Flavonoids and their metabolites: prevention in cardiovascular diseases and diabetes. Diseases 2017, 5, https://doi.org/10.3390/diseases5030019.

14. Fomichev, Y.; Nikanova, L.; Lashin, A. The effectiveness of using dihydroquercetin (taxifolin) in animal husbandry, poultry and apiculture for prevention of metabolic disorders, higher antioxidative capacity, better resistance and realization of a productive potential of organism. Agric. Food. J. Int. Scien. Publ. 2016, 4, 140-159.

15. Shikov, V.; Kammerer, D.R.; Mihalev, K.; Mollov, P.; Carle, R. Antioxidant capacity and colour stability of texture-improved canned strawberries as affected by the addition of rose (Rosa damascena Mill.) petal extracts. Food Res. Int. 2012, 46, 552-556, https://doi.org/10.1016/j.foodres.2011.04.004.

16. Balev, D.; Vlahova-Vangelova, D.; Mihalev, K.; Shikov, V.; Dragoev, S.; Nikolov, V. Application of natural dietary antioxidants in broiler feeds. J. Moun. Agric. Balkans. 2015, 18, 224-232.

17. Jiang, J.; Xiong, Y.L. Natural antioxidants as food and feed additives to promote health benefits and quality of meat products: A review. Meat Sci. 2016, 120, 107-117, https://doi.org/10.1016/j.meatsci.2016.04.005.

18. Piironen, V.; Lampi, A.M. Occurrence and Levels of Phytosterols in Foods. In: Phytosterols as Functional Food Components and Nutraceuticals. Dutta, P.C.; Dekker, M. Inc.: Monticello, NY, USA, 2004; pp. 1-32, https://doi.org/10.1201/9780203913413.

19. Diczfalusy, U. Analysis of cholesterol oxidation products in biological samples. J. AOAC Int. 2004, 87, 467473, https://doi.org/10.1093/jaoac/87.2.467.

20. Valenzuela, A.; Sanhueza, J.; Nieto, S. Cholesterol oxidation: health hazard and the role of antioxidants in prevention. Biol. Res. 2003, 36, 291-302, http://dx.doi.org/10.4067/S0716-97602003000300002.

21. Ponte, P.I.P.; Alves S.P.; Bessa R.J.B.; Ferreira L.M.A.; Gama L.T.; Brás J.L.A.; Fontes C.M.G.A.; Prates J.A.M. Influence of pasture intake on the fatty acid composition, and cholesterol, tocopherols, and tocotrienols content in meat from free-range broilers. Poult. Sci. 2008, 87, 80-88, https://doi.org/10.3382/ps.2007-00148.

22. Cardenia, V.; Rodriguez-Estrada, M. T.; Cumella, F.; Sardi, L.; Della Casa, G.; Lercker, G. Oxidative stability of pork meat lipids as related to high-oleic sunflower oil and vitamin E diet supplementation and storage conditions. Meat Sci. 2011, 88, 271-279, https://doi.org/10.1016/j.meatsci.2010.12.034.

23. Álvarez, R.; Meléndez-Martínez A.J.; Vicario I.M.; Alcalde M.J. Carotenoid and Vitamin A contents in biological fluids and tissues of animals as an effect of the diet: A review. Food Rev. Int. 2015, 31, 319-340, https://doi.org/10.1080/87559129.2015.1015139.

24. Mortensen, A.; Skibsted, L.H. Antioxidant activity of carotenoids in muscle foods. In: Antioxidants in Muscle Foods. Nutritional Strategies to Improve Quatity. Decker, E.; Faustman, C.; Lopez-Bote, C.J. Eds.; Jphn Wiley and Sons, Inc.: New York·Chichester-Weinheim·Brisbane-Singapore-Torornto, NY, USA, 2000; pp. 61-84.

25. Ivanova, S.; Nakev, J.; Nikolova, T.; Vlahova-Vangelova, D.; Balev, D.; Dragoev, S.; Gerrard, D.; Grozlekova, L.; Tashkova, D. Effect of new livestock feeds' phytonutrients on productivity, carcass composition and meat quality in pigs. Czech J. Anim. Sci. 2020, https://doi.org/10.31220/osf.io/jfrvy.

26. Dragoev, S.; Vlahova-Vangelova, D.; Balev, D.; Bozhilov, D.; Dagnon, S. Valorization of waste by-products of rose oil production as feedstuff phytonutrients. Bulg. J. Agric. Sci. 2020, 27, https://doi.org/10.31220/osf.io/cdf9b.

27. El Gharras, H. Polyphenols: food sources, properties and applications - a review. Int. J. Food Sci. Technol. 2009, 44, 2512-2518, https://doi.org/10.1111/j.1365-2621.2009.02077.x. 
28. Tsao, R. Chemistry and biochemistry of dietary polyphenols. Nutrients. 2010, 2, 1231-1246, https://doi.org/10.3390/nu2121231.

29. Vlahova-Vangelova, D.; Balev, D.; Ivanova, S.; Nakev, J.; Nikolova, T.; Dragoev, S.; Gerrard, D. Improving the oxidative stability of pork by antioxidant type phytonutrients. Biointerface Res. Appl. Chem. 2020, 10, 5624-5633, https://doi.org/10.33263/BRIAC103.624633.

30. Martillanes, S.; Rocha-Pimienta, J.; Cabrera-Bañegil, M.; Martín-Vertedor, D.; Delgado-Adámez, J. Chapter 3. Application of phenolic compounds for food preservation: Food additive and active packaging. In: Phenolic compounds - biological activity. Soto-Hernandez, M.; Palma-Tenango, M.; Garcia-Mateos. M.R.; Eds.; IntechOpen Limited; London, UK, 2017; pp. 39-58, https://doi.org/10.5772/66885.

31. Horwitz, W. Official methods of analysis of AOAC International, Methods 922.06 and 954.02, 18th ed.; AOAC International: Gaithersburg, MD, USA, 2005, pp. 40-84.

32. ISO 12966-2:2011. Animal and vegetable fats and oils. Gas chromatography of fatty acid methyl esters Part 2: Preparation of methyl esters of fatty acids. International Organization for Standardization: Geneva, Switzerland, 2011.

33. ISO 12966-1:2014. Animal and vegetable fats and oils. Gas chromatography of fatty acid methyl esters Part 1: Guidelines on modern gas chromatography of fatty acid methyl esters. International Organization for Standardization: Geneva, Switzerland, 2014.

34. ISO 18609:2000. Animal and vegetable fats and oils. Determination of unsaponifiable matter. Method using hexane extraction. International Organization for Standardization: Geneva, Switzerland, 2000.

35. Saptarini, N.M.; Indriyati, W.; Shalihat, A. Colorimetric method for total phytosterols content analysis in soybean (Glycine max), soymilk, and soy yoghurt. J.Chemica. Pharm. Res. 2016, 8, 1458-1464.

36. ISO 12228-1:2014. Part 1: Animal and vegetable fats and oils. Determination of individual and total sterols contents. Gas chromatographic method. International Organization for Standardization: Geneva, Switzerland, 2014,

37. ISO 9936:1997. Animal and vegetable fats and oils - Determination of tocopherols and tocotrienols contents - Method using high-performance liquid chromatography. International Organization for Standardization: Geneva, Switzerland, 1997.

38. Biehler, E.; Mayer, F.; Hoffmann, L.; Krause, E.; Bohn, T. Comparison of 3 spectrophotometric methods for carotenoid determination in frequently consumed fruits and vegetables. J. Food Sci. 2010, 75, C55-C61, https://doi.org/10.1111/j.1750-3841.2009.01417.x.

39. Minitab 16 Statistical software. Computer software. Minitab, Inc.; State College, PA, USA, 2020; Available online: https://www.minitab.com/en-us/

40. Herault, F.; Vincent, A.; Dameron, O.; Le Roy, P.; Cherel, P.; Damon, M. The Longissimus and Semimembranosus muscles display marked differences in their gene expression profiles in pig. Plos One. 2014, 9, https://doi.org/10.1371/journal.pone.0096491.

41. Leseigneur-Meynier, A.; Gandemer, G. Lipid composition of pork muscle in relation to the metabolic type of the fibres. Meat Sci. 1991, 29, 229-241, https://doi.org/10.1016/0309-1740(91)90052-R.

42. Andrés, A.I.; Cava, R.; Mayoral, A.I.; Tejeda, J.F.; Morcuende, D.; Ruiz, J. Oxidative stability and fatty acid composition of pig muscles as affected by rearing system, crossbreeding and metabolic type of muscle fibre. Meat Sci. 2001, 59, 39-47, https://doi.org/10.1016/S0309-1740(01)00050-X.

43. Talmant, A.; Monin, G.; Briand, M.; Dadet, M.; Briand, Y. Activities of metabolic and contractile enzymes in 18 bovine muscles. Meat Sci. 1986, 18, 23-40, https://doi.org/10.1016/0309-1740(86)90064-1.

44. Averette Gatlin, L.; See, M.T.; Hansen, J.A.; Sutton, D.; Odle, J. The effects of dietary fat sources, levels, and feeding intervals on pork fatty acid composition. Journal of Animal Science 2002, 80, 1606-1615, https://doi.org/10.2527/2002.8061606x.

45. Zhang, S.; Knight, T.J.; Stalder, K.J.; Goodwin, R.N.; Lonergan, S.M.; Beitz, D.C. Effects of breed, sex, and halothane genotype on fatty acid composition of pork longissimus muscle. J. Anim. Sci. 2007, 85, 583-591, https://doi.org/10.2527/jas.2006-239.

46. Bertol, T.M.; de Campos, R.M.; Ludke J.V.; Terra, N.N.; de Figueiredo, E.A.; Coldebella, A.; dos Santos Filho, J.I.; Kawski, V.L.; Lehr, N.M. Effects of genotype and dietary oil supplementation on performance, carcass traits, pork quality and fatty acid composition of backfat and intramuscular fat. Meat Sci. 2013, 93, 507-516, https://doi.org/10.1016/j.meatsci.2012.11.012.

47. Shahidi F.; de Camargo, A.C. Tocopherols and tocotrienols in common and emerging dietary sources: occurrence, applications, and health benefits. Int. J. Molec. Sci. 2016, 17, https://doi.org/10.3390/ijms17101745.

48. Kalogeropoulos, N.; Chiou, A.; Gavala, E.; Christea, M.; Andrikopoulos, N.K. Nutritional evaluation and bioactive microconstituents (carotenoids, tocopherols, sterols and squalene) of raw and roasted chicken fed on DHA-rich microalgae. Food Res. Int. 2010, 43, 2006-2013, https://doi.org/10.1016/j.foodres.2010.05.018.

49. Shahidi, F. Oxidative stability of edible oils as affected by their fatty acid composition and minor constituents. ACS Sympos. Ser. 2002, 836, 201-211, https://doi.org/10.1021/bk-2003-0836.ch015. 
50. de Oliveira, V.S.; Ferreira, F.S.; Cople, M.C.R.; da Silva Labre, T.; Augusta, I.M.; Gamallo, O.D.; Saldanha, T. Use of natural antioxidants in the inhibition of cholesterol oxidation: A review. Compreh. Rev. Food Sci. Food Saf. 2018, 17, 1465-1483, https://doi.org/10.1111/1541-4337.12386.

51. Chen, Y.; Deuster, P. Comparison of quercetin and dihydroquercetin: Antioxidant-independent actions on erythrocyte and platelet membrane. Chem.-Biol. Interac. 2009, 182, 7-12, https://doi.org/10.1016/j.cbi.2009.06.007.

52. Teselkin, Y.O.; Babenkova, I.V.; Kolhir, V.K.; Baginskaya, A.I.; Tjukavkina, N.A.; Kolesnik, Y.A.; Selivanova, I.A.; Eichholz, A.A. Dihydroquercetin as a means of antioxidative defence in rats with tetrachloromethane hepatitis. Phytother. Res. 2000, 14, 149-225, https://doi.org/10.1002/(SICI)10991573(200005)14:3<160::AID-PTR555>3.0.CO;2-Y. 